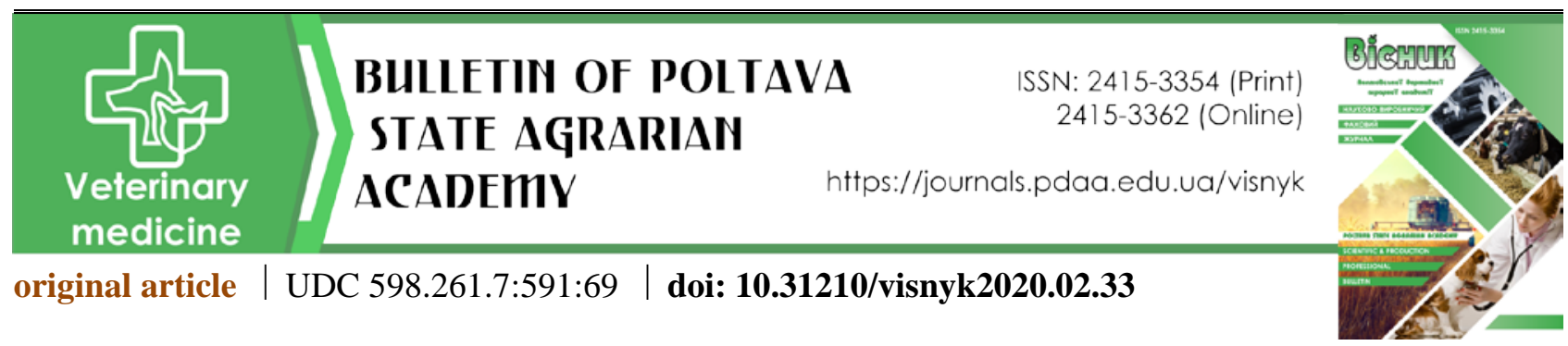

THERAPEUTIC EFFECTIVENESS OF BROMETRONID NEW UNDER QUAIL EIMERIOSIS
Y. Y. Dovhiy
O. V. Rudik*
ORCID (D) $\frac{0000-0002-9927-0646}{0000-0001-9205-7204}$
ORCID (iD

Zhytomyr National Agro-Ecological University, 7, Staryi Blvd., Zhytomyr, 10002, Ukraine

*Corresponding author

E-mail:0969028813@ukr.net

How to Cite

Dovhiy, Y. Y., \& Rudik, O. V. (2020). Therapeutic effectiveness of Brometronid new under quail eimeriosis. Bulletin of Poltava State Agrarian Academy, (2), 259-266. doi: 10.31210/visnyk2020.02.33

The paper presents the results of the scientific-production research, by which it has been established that mono-invasion is observed in quails. The invasion intensity made as follows: E. tenella $-1.1 \pm 0.07$ thousand

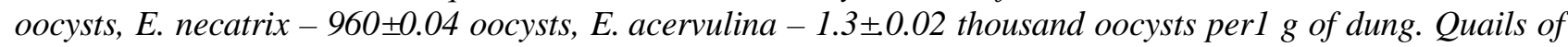
the first experimental group were given Brometronid New preparation at a dose of $2 \mathrm{gr}$ per $1 \mathrm{~kg}$ of compound poultry feed without immune-modulator for 5 days, and the second experimental group received eimeriostatic (Brometronid New) at a dose of $1 \mathrm{~g}$ per $1 \mathrm{~kg}$ of compound poultry feed in combination with immune modulator - Chinese magnolia vine (Schinsandra chinensis) potion at a dose of $1 \mathrm{~cm}^{3}$ per 1 liter of water during 5 days with drinking water. As a result of laboratory analysis of dung samples, on the $14^{\text {th }}$ and $21^{\text {st }}$ days the extenseeffectiveness and intense-effectiveness made $100 \%$. The increase in morphological and biochemical blood indices was observed in the first experimental group. On the $7^{\text {th }}$ day, the number of erythrocytes increased by $18.5 \%, P<0.001$, basophils - by $31.4 \%, P<0.001$, lymphocytes by $7.6 \%, P<0.05$, and on the 14 th day, the number of pseudo-eusinophiles increased by $-7.8 \%, P<0.05$. Such indices as eosinophiles, leukocytes, monocytes on the $7^{\text {th }}$ day tended to increase, and on the $14^{\text {th }}$ day they decreased to minimum physiological indices. Blood biochemical analysis showed that on the $7^{\text {th }}$ day, an increase of crude protein content by $30.9 \%$, $P<0.001$, calcium by $20.3 \% P<0.001$, cholesterol by $0.37 \%, P<0.05$, phosphorus by $49.9 \%, P<0.01$ was registered, and on the $14^{\text {th }}$ day hemoglobin increased by $13.5 \%, P<0.001$, total bilirubin by $5.65 \%, P<0.05$, creatinine by $5.9 \%, P<0.05$, AlAT by $40.5 \%, P<0.01$, AcAT by $8.8 \%, P<0.05$, LF by $35.8 \%, P<0.01$, potassium by $14.6 \%, P<0.001$, glucose by $17.2 \%, P<0.001$, uric acid by $38.2 \%, P<0.01$. The results, received from the second experimental group, testified that on the $7^{\text {th }}$ and 14th days some positive changes in morphological and biochemical blood indices were observed as compared with the $1^{\text {st }}$ day. In morphological indices on the $7^{\text {th }}$ day, an increase in the number of erythrocytes by $17.6 \%, P<0.001$, leukocytes by $10.7 \%, P<0.05$, lymphocytes by $16.3 \%, P<0.001$ was observed, and on the $14^{\text {th }}$ day the number of erythrocytes increased by $32.7 \%$, $P<0.01$ and pseudo-eosinophiles increased by $2.6 \%, P<0.05$. In biochemical indices of the second experimental group on the $7^{\text {th }}$ day, as compared with the $1^{\text {st }}$ day, the increase in total calcium by $20.7 \%, P<0.001$, cholesterol by $37.4 \%, P<0.01$, AcAT by $2.3 \%, P<0.05$, LF by $45.7 \%, P<0.01$, phosphorus by $15.6 \%$, $P<0.001$, potassium by $44.7 \%, P<0.01$, uric acid by $10.2 \%, P<0.05$ was registered, and on the $14^{\text {th }}$ day the content of hemoglobin increased by $26.8 \%, P<0.01$, creatinine by $17.9 \%, P<0.001$, uric acid by $-53 \%$, $P<0.01$, total protein by $17.3 \%, P<0.001$. From the results, obtained in the second group of quails, an increase in hemoglobin content, as well as total calcium, cholesterol, creatinine, alkaline phosphatase, phosphorus, potassium, total protein, uric acid was registered. We consider, these changes were caused by immune stimulating action of Chinese magnolia vine (Scisandra chinensis) potion. The decrease in biochemical indices of total bilirubin, glucose, AlAT as compared with healthy poultry was observed as well.

Key words: tissues, organs, eimeria, toxins, causative agent, metabolites. 


\title{
ТЕРАПЕВТИЧНА ЕФЕКТИВНІСТЬ БРОМЕТРОНІДУ НОВОГО ЗА НАЯВНОСТІ ЕЙМЕРІОЗУ В ПЕРЕПІЛОК
}

\author{
Ю. Ю. Довгій, О. В. Рудік
}

Житомирський національний агроекологічний університет, м. Житомир, Україна

У статті наведені дані результатів науко-виробничих досліджень, які довели, щьо в перепелів ре-

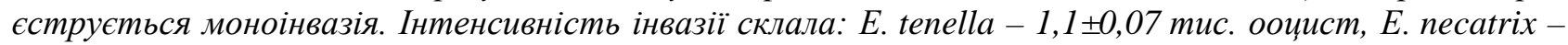

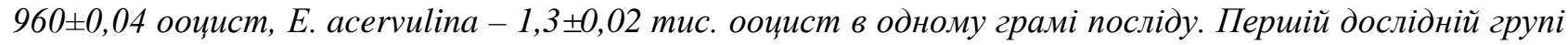
задавали препарат у дозі 2 грами брометроніду нового на 1 кілограм комбікорму, без імуномудулятора упродовж n'яти діб, а другій дослідній групі застосовували еймеріостатик (брометронід новий) у дозі 1 грам на 1 кілограм комбікорму в поєднанні з імуномудулятором - настоянкою лимонника китайського в дозі $1 \mathrm{cм}^{3}$ на 1 літр води упродовж п'яти діб з питною водою. За результатами лабораторного дослідження проб посліду на 14-ту та 21-шу добу екстенсефективність та інтенсефективність склала $100 \%$ У У першій дослідній групі встановлено вірогідне підвищення морфологічних і біохімічних показників у крові. На 7-му добу підвищення кількості еритрочитів на - 18,5 \%, $P<0,001$, базофілів на - 31,4\%, $P<0,001$, лімфоичтів на - 7,6\%, $P<0,05$, та на 14-ту добу псевдоеозинофілів на - 7,8\%, $P<0,05$. Такі показники, як еозинофіли, лейкоџити, моноцити на 7-му добу мали тенденцію до підвищення, а на 14-ту добу знизились до показників фізіологічної межі. При біохімічному досліджені крові встановлено, щчо на 7-му добу відмічали підвищення вмісту загального білка на - 30,9\%, $P<0,001$, загального кальцію на - 20,3\% $P<0,001$, холестерину на - 0,37\%, $P<0,05$, фосфору на - 49,9\%, $P<0,01$, а на 14-ту добу гемоглобіну на - 13,5\%, $P<0,001$, загального білірубіну на $-5,65 \%, P<0,05$, креатиніну на $-5,9 \%, P<0,05$, АлАТ на - 40,5\%, $P<0,01$, AcAT на $-8,8 \%, P<0,05$, ЛФ на - 35,8\%, $P<0,01$, калію на $-14,6 \%, P<0,001$, глюкози на - 17,2\%, $P<0,001$, сечової кислоти на - 38,2 \%, P<0,01. Отримані показники другої дослідної групи свідчили, щяо на 7-му та 14-ту добу відмічали позитивні зміни в морфологічних та біохімічних показниках крові порівняно з 1-ою добою дослідної групи. У морфологічних показниках на 7-му добу спостерігали підвищення: еритроцитів на 17,6\%, $P<0,001$, лейкоцитів на - 10,7\%, $P<0,05$, лімфочитів на - 16,3\%, $P<0,001$, та на 14-ту добу еритрочитів на - 32,7\%, $P<0,01$ і псевдоеозинофілів на -2,6\%, P<0,05. Зміни в біохімічних показниках порівняно з 1-ою добою дослідної другої групи, було встановлено, що на 7-му добу підвищився вміст загального кальиію на - 20,7\%, P<0,001, холестерину на - 37,4\%, P<0,01, АсAT на - 2,3\%, $P<0,05$, ЛФ на - 45,7\%, $P<0,01$, фосфору на $-15,6 \%, P<0,001$, калію на $-44,7 \%, P<0,01$, сечової кислоти на - 10,2\%, $P<0,05$, а на 14-ту добу підвищився вміст гемоглобіну на - 26,8\%, $P<0,01$, креатиніну на - 17,9\%, $P<0,001$, сечової кислоти на $-53 \%, P<0,01$, загального білка на - 17,3\%, $P<0,001.3$ отриманих результатів у другій групі перепелів встановлено підвищення гемоглобіну, загального кальиію, холестерину, креатиніну, лужної фосфатази, фосфору, калію, загального білка, сечової кислоти. Ці зміни відбулися, на нашу думку, внаслідок прояву імуностимулюючої дії настоянки лимонника китайського. Також відмічали зниження біохімічних таких показників: загальний білірубін, глюкози, АлАТ по відноменню до здорової птиці.

Ключові слова: тканини, органи, еймерії, токсини, збудник, метаболіти.

\section{ТЕРАПЕВТИЧЕСКАЯ ЭФФЕКТИВНОСТЬ БРОМЕТРОНИДУ НОВОГО ПРИ ЭЙМЕРИОЗЕ ПЕРЕПЕЛОВ}

\section{Ю. Ю. Довгий, А.В. Рудик}

Житомирский национальный агроэкологический университет, г. Житомир, Украина

В статье приведены данные результатов научно-производственных исследований, которые доказали, что у перепелов регистрируется моноинвазия. Интенсивность инвазии которой составила

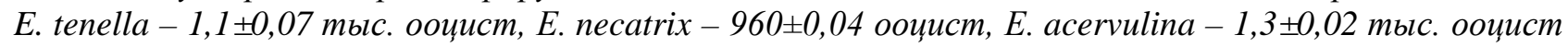
в одном грамме помета. По результатам лабораторного исследования проб помета на 14 и 21 -е сутки екстенсефективнисть и интенсефективнисть составила $100 \%$. В первой опытной группе установлено достоверное повышение морфологических и биохимических показателей в крови. На 7-е сутки отмечали увеличение количества эритроцитов, базофилов, лимфоцитов и на 14-е сутки - псе- 


\section{ВЕТЕРИНАРНА МЕДИЦИНА}

вдоеозинофилов. Такие показатели, как эозинофиль, лейкочиты, моноциты на 7-е сутки имели тенденцию к повышению, а на 14-е снизились до показателей физиологического предела. При биохимическом исследовании крови установлено, что на 7-е сутки отмечали повышение содержания общего белка, общего кальиия, холестерина, фосфора, а на 14-е - гемоглобина, общего билирубина, креатинина, АЛТ, АсАТ, ЛФ, калия, глюкозы, мочевой кислоты. Полученные показатели второй опытной группы свидетельствовали, что в морфологических показателях на 7-е сутки наблюдалось повышение: эритроцитов, лейкоџитов, лимфоцчитов, и на 14-е сутки эритроцитов и псевдоеозинофилив. Из полученных результатов во второй группе перепелов установлено повышение гемоглобина, общего кальция, холестерина, креатинина, щелочной фосфатазы, фосфора, калия, общего белка, мочевой кислотьы. Эти изменения произошли, по нашему мнению, вследствие проявления иммуностимулирующего действия настойки лимонника китайского. Также отмечали снижение биохимических показателей: общего билирубина, глюкозы, АЛТ по отношению к здоровой птице.

Ключевые слова: ткани, органы, еймерии, токсины, возбудитель, метаболиты.

Вступ

Перепільництво - це галузь сільського господарства, яка $є$ однією з найперспективніших та яка динамічно розвивається серед суб'єктів господарювання України і світу. В Японії, Франції, Італії, Англії, Америці, Чилі, Польщі, Чехії, Туреччині, Казахстані та Узбекистані є господарства, де середній річний обіг птиці близько 20 млн. голів перепелів [1-3]. Основним складником для розвитку галузі є створення здорових стад птиці на невеликих територіях [4]. Серед хвороб інвазійної етіології в перепелів відмічається еймеріозна інвазія, яка уражає птицю, що утримуються на глибокій підстилці в кімнатах-брудерах, що сприяє перезараженню перепелів та завдає значних економічних збитків особистим селянським та фермерським господарствам різної форми власності $[5,6]$. У результаті прояву хвороби молодняк відстає у рості та розвитку, знижується м'ясна і яйценосна продуктивність та збільшуються затрати на одиницю отриманої продукції.

Науковці відзначають, що в перепелів паразитують такі види еймерій: E. tsunodai, E. uzura, E. bateri, E. tenella, E. necatrix, E. colurnicis, E. lophortygus, E. acervulina, E. тахіта, які різняться місцем локалізації, ступенем вірулентності та репродуктивною здатністю [7-9].

Негативний вплив на організм птиці проявляють технологічні прийоми хвороби, які сприяють розвитку стресу та імунодефіцитних станів серед птице поголів'я. Для підвищення опірності організму птахам при лікуванні хвороб інвазійної етіології застосовують імуномодулятори природнього і синтетичного походження, які впливають на прискорення процесу відновлення показників загального стану перепелів [10-15]. У країнах Стародавньго світу не вивчене питання щодо поширення, патогенезу, діагностики, профілактично-лікувальних заходів за наявності еймеріозу в перепелів та не висвітлені в наукових здобутках. Проблематика залишається актуальною, через це виникає питання про необхідність наукових досліджень у плані розробки науково-обѓрунтованих схем лікування та профілактики, що стимулює для подальших досліджень еймеріозної інвазії [16].

Мета роботи - встановити видовий склад збудника, вивчити ефективність брометроніду нового в поєднанні з лимонником китайським та встановити вплив на показники крові у перепелів.

\section{Матеріали та методи досліджень}

Матеріалом для науково-виробничих досліджень були проби крові та посліду, відібрані у хворих перепелів на 1-шу, 7-му та 14-ту добу досліду в господарстві ФГ «Миколай» Житомирського району Житомирської області упродовж 2018-2019 рр. На початку досліджень було сформовано за методом пар аналогів контрольну та дві дослідні групи. Для досліду відібрали 150 голів перепелів японської

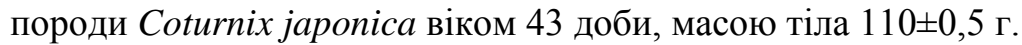

Першій дослідній групі задавали еймеріостатик брометронід новий у вигляді порошку, який згодовували разом з комбікормом у дозі 2 г/1 кг корму упродовж п'яти діб.

Другій дослідній групі задавали еймеріостатик брометронід новий у вигляді порошку, змішуючи разом із кормом у розрахунку 2 г/1 кг, який згодовували упродовж п'яти діб в поєднанні 3 імуномодулятором настоянки лимонника китайського в дозі $1 \mathrm{~cm}^{3}$ на 1 л води.

Контрольній групі згодовували комбікорм згідно з віковою нормою без лікарських засобів.

Лабораторні дослідження проводили в Житомирській державній регіональній лабораторії Держпродспоживслужби в Житомирській області, клініко-діагностичній лабораторії кафедри внутрішніх хвороб тварин та фізіології і на кафедрі паразитології, ветеринарно-санітарної експертизи та зоогігіє- 


\section{ВЕТЕРИНАРНА МЕДИЦИНА}

ни факультету ветеринарної медицини ЖНАЕУ у двох напрямах.

Дослідження копрологічні проводили згідно з ДСТУ 5079:2008 у такій послідовності:

- ступінь ураження птиці еймеріями визначали за методом Фюллеборна та «Способом копрологічної діагностики гельмінтозів і еймеріозів» (патент на корисну модель № 66165, Ю. Ю. Довгій та ін., 2013 р.;

- видову належність виявлених ооцист визначали на підставі морфологічних (колір, форма, розмір, кількість оболонок, наявність кришечок на полюсах) і біологічних (ступінь розвитку зародка) ознак за А. Н. Чертковою (1959), І. С. Дахно (2001).

Гематологічні дослідження включали визначення морфологічних та біохімічних показників крові, яку відбирали на 1-шу, 7-му та 14-ту добу науково-господарського досліду з підкрильцевої вени vепа axillaris у дві пробірки від 2-х до 4-х см³. У пробірку, яка призначалась для морфологічних досліджень, вносили 2-3 краплі антикоагулянта (гепарин).

Для досліджень крові використовували загальноприйняті методики: визначали кількість еритроцитів, лейкоцитів за допомогою камери Горяєва, лейкограму виводили шляхом підрахунку клітин крові в мазках (фіксували рідиною Нікіфорова та фарбували за Романовським-Гімза) за допомогою мікроскопа Micros MC-50 з камерою CAM V200.

Біохімічні показники сироватки крові визначали напівавтоматичним біохімічним аналізаторам типу ERBA (Чехія) з набором реактивів фірми DAC, виробник - Франція та контрольних сироваток до них.

У ході виконання роботи дотримувалися «Загальних принципів експериментів на тваринах», які ухвалено на Першому національному конгресі з біоетики (м. Київ, 2001 р.), узгоджено з положеннями «Європейської конвенції про захист хребетних тварин, які використовуються для експериментальних та інших наукових цілей» (м. Страсбург, 1987 р.) і відповідають Закону України № 692 «Про захист тварин від жорстокого поводження» (3447-IV) від 21.02.2006 p.

Отримані результати обробляли з використанням програми Microsoft Excel 2003. Вірогідність різниці між показниками оцінювали за t-критерієм Стьюдента та Фішера.

\section{Результати досліджень та їх обговорення}

У результаті наукових досліджень виявлено такі збудники еймеріозу в перепелів: E. tenella, E. necatrix, E. acervulina, де інтенсивність інвазії до лікування складала $3,36 \pm 1,1$ тисяч ооцист у грамі

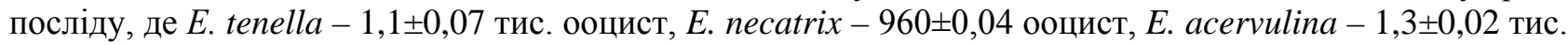
ооцист у грамі посліду. Внаслідок проведеної лікувальної терапії перепелам, що хворі на еймеріоз, на 14-ту та 21-шу добу екстенсефективність та інтенсефективність склала $100 \%$, оскільки ооцист не виявлено.

За результатами досліджень у першій дослідній групі встановлено вірогідне підвищення морфологічних показників (табл. 1) на 7-му та 14-ту добу порівняно з 1-ою добою досліду.

1. Морфологічні показники крові перепілок у разі за лікування "Брометронідом новим", $(M \pm m, n=20)$

\begin{tabular}{|c|c|c|c|c|c|}
\hline \multirow{2}{*}{\multicolumn{2}{|c|}{ Показники }} & \multirow{2}{*}{$\begin{array}{c}\text { Контрольна } \\
\text { група }\end{array}$} & \multicolumn{3}{|c|}{ Дослідна група 1} \\
\hline & & & 1-ша доба & 7-ма доба & 14-та доба \\
\hline \multicolumn{2}{|c|}{ Еритроцити, Т/л } & $3,7 \pm 0,44$ & $3,08 \pm 0,4$ & $3,78 \pm 0,44^{* * *}$ & $3,48 \pm 0,42$ \\
\hline \multicolumn{2}{|c|}{ Лейкоцити, Г/л } & $43,4 \pm 1,51$ & $41,7 \pm 1,48$ & $43,3 \pm 1,47$ & $37,1 \pm 1,39 *$ \\
\hline \multirow{5}{*}{ 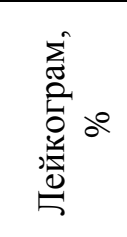 } & Базофіли & $2,5 \pm 0,36$ & $2,0 \pm 0,32$ & $2,9 \pm 0,39 * *$ & $1,8 \pm 0,3$ \\
\hline & Еозинофіли & $9,8 \pm 0,71$ & $11,3 \pm 0,77$ & $13,7 \pm 0,84$ & $10,3 \pm 0,73 * * *$ \\
\hline & Псевдоеозинофіли & $30,7 \pm 1,27$ & $29,3 \pm 1,24$ & $17,3 \pm 0,95$ & $31,8 \pm 1,29 *$ \\
\hline & Лімфоцити & $43,6 \pm 1,51$ & $46,3 \pm 1,56$ & $50,1 \pm 1,62 *$ & $46,2 \pm 1,55$ \\
\hline & Моноцити & $13,4 \pm 0,83$ & $11,1 \pm 0,76$ & $10,8 \pm 0,75$ & $9,9 \pm 0,72$ \\
\hline
\end{tabular}

Примітки: ${ }^{*}-\mathrm{p}<0,05, * *-\mathrm{p}<0,01, * * *-\mathrm{p}<0,001-$ порівняно з $1-$-шою добою досліду.

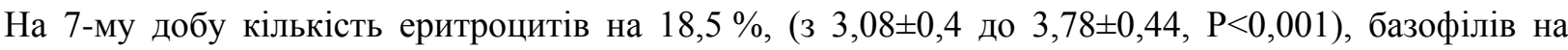

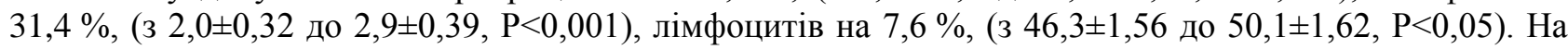

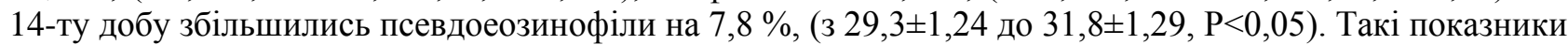
як: еозинофіли, лейкоцити, моноцити на 7-му добу мали тенденцію до підвищення, а на 14-ту добу знизились до показників фізіологічної межі.

За результатами біохімічних показників встановлено що після лікування еймеріостатиком (брометронід новий) деякі показники сироватки крові підвищились на 7-му та на 14-ту добу по відношенню 
до 1-шої доби (табл. 2).

2. Біохімічні показники крові перепілок у разі лікуванні «Брометронідом новим», $(M \pm m, n=20)$

\begin{tabular}{|l|c|c|c|c|}
\hline \multirow{2}{*}{ Показники } & Контрольна & \multicolumn{3}{|c|}{ Дослідна група 1 } \\
\cline { 3 - 5 } & група & 1 -ша доба & 7 -ма доба & $14-$-а доба \\
\hline Гемоглобін, г/л & $115,3 \pm 2,46$ & $113,8 \pm 2,44$ & $90,4 \pm 2,18$ & $131,5 \pm 2,6^{* * *}$ \\
\hline Загальний білок, г/л & $29,3 \pm 1,24$ & $28,6 \pm 1,22$ & $41,4 \pm 1,47 * * *$ & $30,5 \pm 1,26$ \\
\hline Загальний кальцій, ммоль/л & $4,1 \pm 0,46$ & $3,93 \pm 0,45$ & $4,92 \pm 0,50^{* * *}$ & $3,3 \pm 0,41$ \\
\hline Загальний білірубін, мкмоль/л & $18,1 \pm 0,97$ & $16,7 \pm 2,96$ & $15,3 \pm 0,89$ & $17,7 \pm 0,96 *$ \\
\hline Холестерин, ммоль/л & $5,72 \pm 0,54$ & $5,32 \pm 0,52$ & $4,12 \pm 0,46$ & $5,34 \pm 0,53$ \\
\hline Креатинін, мкмоль/л & $47,0 \pm 0,49$ & $40,2 \pm 1,4$ & $22,7 \pm 1,09$ & $42,4 \pm 1,49^{*}$ \\
\hline АлАТ, Од/л & $6,7 \pm 0,56$ & $5,7 \pm 0,54$ & $6,08 \pm 0,56$ & $8,7 \pm 0,99^{* * *}$ \\
\hline АсАТ, Од/л & $341,0 \pm 4,7$ & $325,0 \pm 4,1$ & $335,0,4 \pm 4,19$ & $356,2 \pm 4,32^{*}$ \\
\hline ЛФ, ОД/л & $1385,2 \pm 8,53$ & $1345,0 \pm 8,4$ & $1415,2 \pm 8,63$ & $2093,7 \pm 10,4 * *$ \\
\hline Фосфор, ммоль/л & $1,51 \pm 0,28$ & $1,45 \pm 0,27$ & $2,89 \pm 0,39 * *$ & $1,27 \pm 0,25$ \\
\hline Калій, ммоль/л & $2,21 \pm 0,33$ & $2,05 \pm 0,32$ & $2,4 \pm 0,35 * * *$ & $2,35 \pm 0,35$ \\
\hline Глюкоза, ммоль/л & $8,3 \pm 0,66$ & $7,72 \pm 0,63$ & $7,3 \pm 0,95$ & $9,32 \pm 0,7 * * *$ \\
\hline Сечова кислота, мкмоль/л & $242,7 \pm 3,57$ & $213,5 \pm 3,35$ & $464,1 \pm 4,94$ & $345,2 \pm 4,26 * *$ \\
\hline
\end{tabular}

Примітки: ${ }^{*}-\mathrm{p}<0,05,{ }^{* *}-\mathrm{p}<0,01, * * *-\mathrm{p}<0,001-$ порівняно 31 -ою добою досліду.

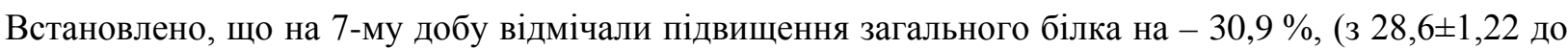
$41,4 \pm 1,47, \mathrm{P}<0,001)$, загального кальцію на - 20,3 \% (з 3,92 $\pm 0,45$ до 4,92 $\pm 0,50, \mathrm{P}<0,001$ ), холестерину

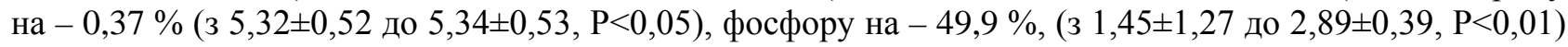
та на $14-$ ту добу гемоглобіну на - 13,5 \%, ( $113,8 \pm 2,44$ до $131,5 \pm 2,6, \mathrm{P}<0,001)$, загального білірубіну

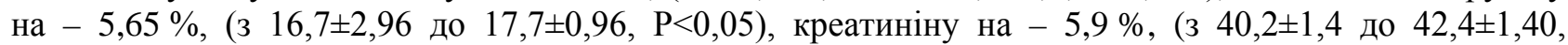

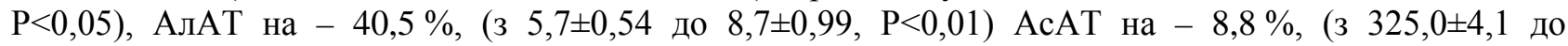

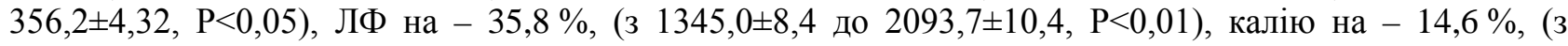
$2,05 \pm 0,32$ до $2,4 \pm 0,35, \mathrm{P}<0,001)$, глюкози на - 17,2 \%, (з 7,72 $\pm 0,63$ до 9,32 $\pm 0,7, \mathrm{P}<0,001)$ сечової кисло-

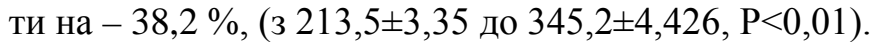

Аналізуючи результати морфологічних досліджень другої дослідної групи (табл. 3), було встановлено, що на 7-му та 14-ту добу відмічали позитивні зміни в морфологічних показниках з 1-ою добою дослідної групи.

3. Морфологічні показники крові перепілок у разі комплексного лікування «Брометронідом новим» у посднанні з настоянкою лимонника китайського, $(M \pm m, n=20)$

\begin{tabular}{|c|c|c|c|c|c|}
\hline \multirow{2}{*}{\multicolumn{2}{|c|}{ Показники }} & \multirow{2}{*}{$\begin{array}{c}\text { Контрольна } \\
\text { група }\end{array}$} & \multicolumn{3}{|c|}{ Дослідна група 2} \\
\hline & & & 1-ша доба & 7-ма доба & 14-та доба \\
\hline \multicolumn{2}{|c|}{ Еритроцити, Т/л } & $3,7 \pm 0,44$ & $3,08 \pm 0,4$ & $3,74 \pm 0,44 * * *$ & $4,58 \pm 0,49 * *$ \\
\hline \multicolumn{2}{|c|}{ Лейкоцити, Г/л } & $43,4 \pm 1,51$ & $41,7 \pm 1,48$ & $46,7 \pm 1,6 *$ & $32,5 \pm 1,3$ \\
\hline \multirow{5}{*}{ 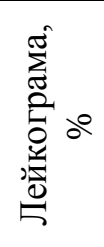 } & Базофіли & $2,5 \pm 0,36$ & $2,0 \pm 0,32$ & $1,9 \pm 0,31$ & $1,6 \pm 0,29$ \\
\hline & Еозинофіли & $9,8 \pm 0,71$ & $11,3 \pm 0,77$ & $10,3 \pm 0,73$ & $10,9 \pm 0,7$ \\
\hline & Псевдоеозинофіли & $30,7 \pm 1,27$ & $29,3 \pm 1,24$ & $29,7 \pm 1,25$ & $30,1 \pm 1,25^{*}$ \\
\hline & Лімфоцити & $43,6 \pm 1,51$ & $46,3 \pm 1,56$ & $55,3 \pm 1,7 * * *$ & $45,4 \pm 1,54$ \\
\hline & Моноцити & $13,4 \pm 0,83$ & $11,1 \pm 0,76$ & $8,0 \pm 0,64$ & $11,9 \pm 0,79$ \\
\hline
\end{tabular}

Примітки: ${ }^{*}-\mathrm{p}<0,05,{ }^{*}-\mathrm{p}<0,01, * * *-\mathrm{p}<0,001-$ порівняно 3 1-шою добою досліду.

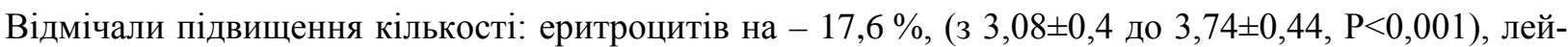

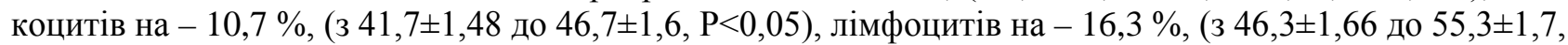

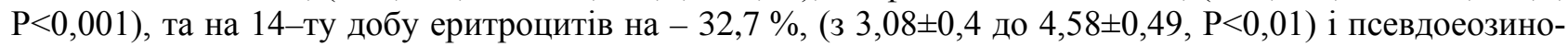

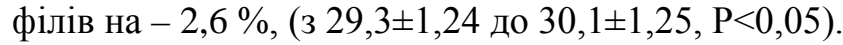

У таких показниках, як базофіли, еозинофіли, моноцити на 7-му і 14-ту добу вірогідних змін не виявлено, показники коливались у фізіологічних межах. 
ВЕТЕРИНАРНА МЕДИЦИНА

4. Біохімічні показники крові перепілок у разі лікування «Брометронідом новим» у посднанні з настоянкою лимонника китайського, $(M \pm m, n=20)$

\begin{tabular}{|l|c|c|c|c|}
\hline \multirow{2}{*}{ Показники } & \multirow{2}{*}{ Контрольна група } & \multicolumn{3}{|c|}{ Дослідна група 2 } \\
\cline { 3 - 5 } & & 1 -ша доба & 7 -ма доба & $14-$-а доба \\
\hline Гемоглобін, г/л & $138,2 \pm 2,7$ & $106,9 \pm 2,3$ & $98,8 \pm 2,28$ & $146,1 \pm 2,7 * * *$ \\
\hline Загальний білок, г/л & $38,5 \pm 1,4$ & $50,2 \pm 1,62$ & $36,5 \pm 1,38^{* * *}$ & $31,3 \pm 1,28$ \\
\hline Загальний кальцій, ммоль/л & $3,4 \pm 0,42$ & $3,5 \pm 0,42$ & $4,41 \pm 0,48$ & $3,74 \pm 0,44$ \\
\hline Загальний білірубін, мкмоль/л & $21,3 \pm 1,4$ & $17,5 \pm 0,95$ & $14,6 \pm 0,87$ & $13,5 \pm 0,84$ \\
\hline Холестерин, ммоль/л & $4,8 \pm 0,3$ & $4,98 \pm 0,51$ & $4,44 \pm 0,48$ & $7,96 \pm 0,64 * *$ \\
\hline Креатинін, мкмоль/л & $38,5 \pm 1,42$ & $42,2 \pm 1,4$ & $42,3 \pm 1,49$ & $51,4 \pm 1,64 * * *$ \\
\hline АлАТ, Од/л & $7,2 \pm 0,6$ & $22,9 \pm 1,0$ & $12,8 \pm 0,82$ & $15,9 \pm 0,91$ \\
\hline АсАТ, Од/л & $425,9 \pm 4,7$ & $329,1 \pm 4,1$ & $336,6 \pm 4,2 *$ & $311,0 \pm 4,04$ \\
\hline ЛФ, ОД/л & $1095,1 \pm 7,6$ & $852,9 \pm 6,6$ & $1569,8 \pm 9,08^{* *}$ & $781,7 \pm 6,41$ \\
\hline Фосфор, ммоль/л & $1,87 \pm 0,31$ & $2,0 \pm 0,32$ & $2,37 \pm 0,35^{* * *}$ & $1,74 \pm 0,3$ \\
\hline Калій, ммоль/л & $1,6 \pm 0,29$ & $1,05 \pm 0,23$ & $1,9 \pm 0,31^{* *}$ & $1,35 \pm 0,26$ \\
\hline Глюкоза, ммоль/л & $12,3 \pm 0,8$ & $20,9 \pm 1,0$ & $17,7 \pm 0,96^{* * *}$ & $7,7 \pm 0,63$ \\
\hline Сечова кислота, мкмоль/л & $458,3 \pm 4,9$ & $362,4 \pm 4,3$ & $403,2 \pm 4,6 *$ & $787,3 \pm 6,43^{* *}$ \\
\hline
\end{tabular}

Примітки: ${ }^{*}-\mathrm{p}<0,05,{ }^{* *}-\mathrm{p}<0,01, * * *-\mathrm{p}<0,001-$ порівняно 31 -ою добою досліду.

Зміни в біохімічних показниках (табл. 4) порівняно з 1-ою добою дослідної другої групи були ви-

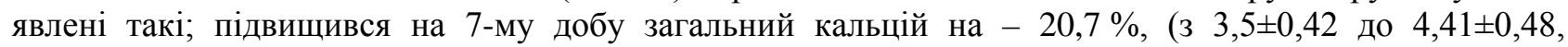

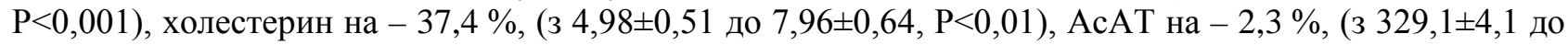

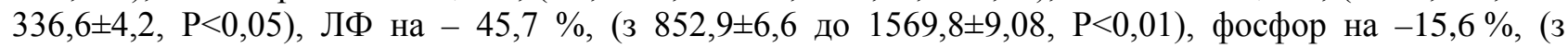
$2,0 \pm 0,32$ до $2,37 \pm 0,35, \mathrm{P}<0,001)$, калій на $-44,7 \%$, ( з $1,05 \pm 0,23$ до $1,9 \pm 0,31, \mathrm{P}<0,01)$, сечова кислота на - 10,2 \%, ( $3362,4 \pm 4,3$ до 403,2 $\pm 4,6, \mathrm{P}<0,05$ ), а на 14-ту добу підвищились вміст гемоглобіну на -

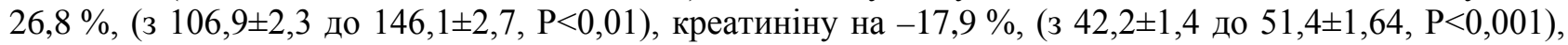
сечової кислоти на $-53 \%$, (з $362,4 \pm 4,3$ до $787,3 \pm 6,43, \mathrm{P}<0,01)$, загального білка на $-17,3 \%$, (3 $30,2 \pm 1,62$ до $36,5 \pm 1,38, \mathrm{P}<0,001)$.

Зважаючи на результати досліджень, встановлено, що ефективність діючої речовини еймеріостатика на еймерії склала $100 \%$, на 14-ту і 21-шу добу досліду.

У крові першої дослідної групи перепелів на 7-му та 14-ту добу після застосування еймеріостатика, порівнюючи з початковим зниженням, було зафіксовано підвищення вмісту гемоглобіну, загального білка, кальцію, білірубіну, холестерину, креатиніну, фосфору, калію, глюкози та сечової кислоти.

Відновлення білкового обміну, АлАТ, АсАТ вплинуло на стимулювання детоксикаційної функції печінки, відновлення паренхіми органу, щоб не допустити гепатиту та жирової інфільтрації.

Відновлення гематологічних показників у перепелів після лікування свідчило про фізіологічний перебіг обміних процесів у організмі птахів.

Через звільнення організму від токсинів деякі морфологічні показники крові в першій дослідній групі відновилися до фізіологічної межі. Також підвищення таких показників, як еритроцити, псевдоеозинофіли $є$ свідченням позитивного впливу на гемопоез унаслідок звільнення організму від збудників.

Аналізуючи результати досліджень другої групи, де застосовували бровермектин новий у поєднанні з настоянкою лимонника китайського, на відміну від монотерапії проявив тенденцію до підвищення таких показників, як еритроцити, псевдоеозинофіли, моноцити за рахунок імуностимулюючої дії лимонника китайського.

При звільненні організму від ооцист, на 14-ту добу, отримали показники, які свідчили про регуляцію білкового, вуглеводного обміну речовин. Це все мало вплив на легеневі показники дихання, що сприяло окисненню продуктів обміну до вуглекислого газу та води, не допускаючи проникнення недоокислених метаболітів.

Також встановлено підвищення гемоглобіну, загального кальцію, холестерину, креатиніну, лужної фосфатази, фосфору, калію, загального білка, сечової кислоти. На нашу думку ці зміни відбулися через імуностимулюючу дію настоянки лимонника китайського.

Відмічали зниження біохімічних показників: загального білірубіну, глюкози, АлАТ по відношенню до здорової птиці.

Отже, отримані дані підтверджують й інші автори, які встановили, що комбіновані схеми ліку- 


\section{ВЕТЕРИНАРНА МЕДИЦИНА}

вання за наявності еймеріозу в перепелів більш ефективні порівняно з монотерапією, також відмічається нормалізація гематологічних показників [17-19].

Новизна наших науково-виробничих досліджень полягає в тому, що ми апробували, розробили дозування та період застосування настоянки лимонника китайського як імуностимулятора в перепільництві за наявності еймеріозу.

Отримані результати є цінними для лікаря ветеринарної медицини, який працює у фермерському господарстві та матиме змогу швидко відновити гематологічні показники крові та продуктивність у птиці цього виду.

\section{Висновки}

Дослідження доводять, що препарат «Брометронід новий» проявив сто відсоткову ефективність при боротьбі з еймеріозом у перепелів. У крові першої дослідної групи на 7-му та 14-ту добу після застосування еймеріостатика встановлено підвищення вмісту гемоглобіну, загального білка, кальцію, білірубіну, холестерину, креатиніну, фосфору, калію, глюкози та сечової кислоти та відновлення білкового обміну. Більш ефективною $є$ схема лікування з бровермектином новим у поєднанні 3 настоянкою лимонника китайського, застосування якої вплинуло на такі показники: гемоглобін, креатинін, фосфор, сечова кислота, еритроцити та позитивно вплинула на еритропоез, що підтверджує імуностимулюючі властивості лимонника китайського.

Перспективи подальших досліджень полягають у розробці нових схем лікування, способу застосування та дозування лимонника китайського за наявності еймеріозу в перепелів.

\section{References}

1. Rahman, A. N. M. A., Hoque, M. N., Talukder, A. K., \& Das, Z. C. (2016). A survey of Japanese quail (Coturnix coturnix japonica) farming in selected areas of Bangladesh. Veterinary World, 9 (9), 940-947. doi: 10.14202/vetworld.2016.940-947.

2. Luchese, F. C., Perin, M., Aita, R. S., Mottin, V. D., Molento, M. B., \& Monteiro, S. G. (2007). Prevalence of Eimeria species in industrial and alternative bred chicken. Brazilian Journal of Veterinary Research and Animal Science, 44 (2), 81-86.

3. Mohammad, N. H. (2012). A study on the pathological and diagnosis of eimeria species infection in Japanese quaiL. Basrah Journal of Veterinary Research, 11 (1), 318-333. doi: 10.33762/bvetr.2012.54858.

4. Yatusevich, A. I. (2005) Rekomendacii po borbe s ejmeriozami kurinyh ptic: metod. Rekomendacii. Vitebsk: MSHIPRB, RO "Belpticeprom”, VGAVM [In Russian].

5. Yatusevich, A. I. (1992) Rekomendacii po borbe s ejmeriozami i izosporozami zhivotnyh. Vitebsk: MSHIPRB, RO "Belpticeprom”, VGAVM [In Russian].

6. Ruff, M. D., Fagan, J. M., \& Dick, J. W. (1984). Pathogenicity of coccidia in Japanese Quail (Coturnix coturnix japonica). Poultry Science, 63 (1), 55-60. doi: 10.3382/ps.0630055.

7. Nakai, Y., Tsuchiya, H., \& Takahashi, S. (1992). Cultivation of Eimeria tenella in Japanese Quail Embryos (Coturnix coturnix japonica). The Journal of Parasitology, 78 (6), 1024-1026. doi: $10.2307 / 3283224$.

8. Teixeira, M., Teixeira, F. W. L., \& Lopes, C. W. G. (2004). Coccidiosis in Japanese quails (Coturnix japonica) characterization of a naturally occurring infection in a commercial rearing farm. Revista Brasileira de Ciência Avícola, 6 (2), 129-134. doi: 10.1590/S1516-635X2004000200010.

9. Zaikina, H. V. (2013) Helmintozno protozoini invazii silskohospodarskoi ptytsi (poshyrennia, skryninh dezinvaziinykh zasobiv). Extended abstract of candidate's. Kyiv [In Ukrainian].

10. Korolenko, L. S., Veselyi, V. A., Korolenko, I. I., Marmalkina, T. V., \& Zaikina, G. V. (2012). (2012). Eimerioz sviiskoi ptytsi u hospodarstvakh tsentralnykh oblastei Ukrainy, zakhody borotby i profilaktyky. Veterynarna Medytsyna Ukrainy, 4 (194), 21-22 [In Ukrainian].

11. Yevstafieva, V. O., Klymenko, O. S., \& Khyzhnia, L. Iu. (2010) Monitorynh kyshkovykh parazytoziv kurei pryvatnykh hospodarstv Poltavskoi oblasti. Visnyk Poltavskoi Derzhavnoi Ahrarnoi Akademii, 4, 130-131 [In Ukrainian].

12. Korolenko, L. S., Kovalenko, I. I., \& Marmalkina, T. V. (2010). Monitorynh helmintoziv ta eimerioziv sviiskoi ptytsi $\mathrm{v}$ hospodarstvakh stepovoi zony Ukrainy ta likuval profilaktychni zakhody. Veterynarna Medytsyna: Parazytolohiia, 7, 14-16 [In Ukrainian].

13. Semenko, O. V. (2014). Deiaki osoblyvosti poshyrennia ta zakhodiv boro-tby z eimeriozom ptytsi. Suchasne Ptakhivnytstvo, 8, 7-11 [In Ukrainian]. 


\section{ВЕТЕРИНАРНА МЕДИЦИНА}

14. Zherebov, M. Y. (2015). Pro stan roboty haluzi ptakhivnytstva Kyivshchyny u 2014 rotsi. Suchasne Ptakhivnytstvo, 1-2, 10-13 [In Ukrainian].

15. Kucher, V. A., \& Zaharenko, M. O. (2011). Parametry mikroklimatu ta otsinka sposobiv utrymannia perepeliv u rekonstruiovanykh prymishchenniakh. Suchasne Ptakhivnytstvo, 4, 6-9 [In Ukrainian].

16. Verzhychovsky, O., Kolos, Y., Tytarenko, A. (2007). Epizootychnyi stan ptakhivnytstva v Ukraini. Veterynarna Medytsyna Ukrainy, 6, 8-10 [In Ukrainian].

17. Latif, A. A., Fazal, S., Manzoor, F., Maqbool, A., Asghar, S., Wajid, I., \& Ashraf, A. (2016). A Comparative Study on Prevalence of Coccidian Parasites in Broiler Chicken (Gallus gallus domesticus), Japanese Quail (Coturnix coturnix japonica) and Wild Pigeon (Columba livia). Pakistan Journal of Zoology, 48, 134-139.

18. Sokół, R., Gesek, M., Raś-Noryńska, M., Michalczyk, M., \& Koziatek, S. (2015). Biochemical parameters in Japanese quails Coturnix coturnix japonica infected with coccidia and treated with Toltrazuril. Polish Journal of Veterinary Sciences, 18 (1), 79-82. doi: 10.1515/pjvs-2015-0010.

19. Dovhiy, Y., \& Rudik, O. (2019). Therapentic effectiveness of robenkox and hematological body indices in qualits under emeriosis. Agrarian Bulletin of The Black Sealittoral, 94, 15-21. doi: 10.37000/abbsl.2019.94.

Стаття надійшла до редакції 20.05.2020 р.

Довгій Ю. Ю., Рудік О. В. Терапевтична ефективність брометроніду нового за наявності еймеріозу в перепілок. Вісник ПДАА. 2020. № 2. С. 259-266.

(С) Довгій Юрій Юрійович, Рудік Олександр Васильович, 2020 
Відповідальний редактор: Мельничук $B . B$.

Літературні редактори: Дедухно А. B.

Переклад англійською мовою: Панкова T. O.

Куратор з індексів DOI: Жукова В. K.

Комп'ютерна верстка та дизайн: Свєшнікова A. O.

Під час створення макету було використано матеріали, які знаходяться у вільному доступі мережі Інтернет.

Формат 60х90/8. Ум. друк. арк. 16,6. Тираж 300 пр. Зам. № 53.

Видавець і виготовлювач: Полтавська державна аграрна академія.

Адреса: 36003, м. Полтава, вул. Григорія Сковороди, 1/3.

Свідоцтво суб’єкта видавничої справи ДК № 2174 від 26.04.2005 p. 